\title{
オーステナイト系ステンレス鋼製配管の溶接施工過程に 伴う残留応力分布の変化挙動
}

\author{
伊 原 涼 平 ${ }^{*}$ 橋 本匡 史 ${ }^{* *}$ 望 月 正 人*** \\ Variation Behavior of Residual Stress Distribution by Manufacturing Processes \\ in Welded Pipes of Austenitic Stainless Steel
}

by

\author{
Ryohei Ihara ${ }^{*}$, Tadafumi Hashimoto ${ }^{* *}$ and Masahito Mochizuki ${ }^{* * *}$
}

\begin{abstract}
Stress corrosion cracking (SCC) has been observed near heat affected zone (HAZ) of primary loop recirculation pipes made of low-carbon austenitic stainless steel type $316 \mathrm{~L}$ in the nuclear power plants. For the non-sensitization material, residual stress is the important factor of SCC, and it is generated by machining and welding. In the actual plants, welding is conducted after machining as manufacturing processes of welded pipes. It could be considered that residual stress generated by machining is varied by welding as a posterior process. This paper presents residual stress variation due to manufacturing processes of pipes using X-ray diffraction method. Residual stress distribution due to welding after machining had a local maximum stress in HAZ. Moreover, this value was higher than residual stress generated by welding or machining. Vickers hardness also had a local maximum hardness in HAZ. In order to clarify hardness variation, crystal orientation analysis with EBSD method was performed. Recovery and recrystallization were occurred by welding heat near the weld metal. These lead hardness decrease. The local maximum region showed no microstructure evolution. In this region, machined layer was remained. Therefore, the local maximum hardness was generated at machined layer. The local maximum stress was caused by the superposition effect of residual stress distributions due to machining and welding. Moreover, these local maximum residual stress and hardness are exceeded critical value of SCC initiation. In order to clarify the effect of residual stress on SCC initiation, evaluation including manufacturing processes is important.
\end{abstract}

Key words : Stress corrosion cracking, Residual stress, Machining, Welding, Superposition effect, Manufacturing processes

\section{1 緒言}

東日本大震災は地域のみならず原子力発電所にも甚大 な被害を及ぼし, 将来的な原子力発電のあり方が問われ るようになった。電力供給や環境問題の観点からも原子 力発電が果たして来た役割は大きいものの, 今後, 運転 を継続，または発電所を廃炉するにしても，原子力プラ ントの全寿命を通じて更なる安全性を求めていく姿勢が 重要となる。原子力発電における安全性向上のために, 原因解明が望まれる問題の一つとして応力腐食割れ (Stress Corrosion Cracking : SCC) が挙げられる. SCC は沸騰水型原子力発電プラントの低炭素オーステナイト 系ステンレス鋼 SUS316L 製の再循環系配管における溶 接熱影響部 (Heat Affected Zone : HAZ) 等に顕在化して いる. ${ }^{1) \sim 3)} \mathrm{SCC}$ は材料, 環境, 力学的要因の重畳により 発生するとされており, それぞれの要因として, 鋭敏化, 溶存酸素, 残留応力等が挙げられる. 炭素量を減少させ ることにより非鋭敏化材として開発された SUS316L 鋼 においては，以前まで主要因とされてきた鋭敏化はほぼ
確認されなかった。 また, 環境的対策としての溶存酸素 を低下させる脱気運転もSCC に対して明確な効果が得 られなかったことから, 力学的要因としての残留応力に 注目が集まっている.

実機の配管における残留応力は，その配管を溶接施工 する際に，溶接熱によってはもちろん，溶接作業前に施 される機械加工によっても発生することが知られている. これらの施工により発生する残留応力に関しては様々な 研究が行われており，有用な知見が得られている。機械 加工により生じる残留応力は, 表面から数十から数百 $\mu \mathrm{m}$ と極浅い表面硬化層に打いて極めて高い值を示す.4), 5) SCC の発生条件として, ビッカース硬さが HV270 以上

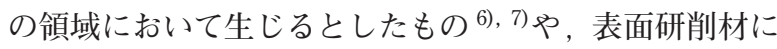
対して高温高圧水環境中で 4 点曲げビーム法を行った結 果から SCC 発生応力のしきい值は $600 \mathrm{MPa}$ である ${ }^{5)}$ との 報告がなされているなど, 他にも機械加工が SCC 発生お よび進展を促進させるとの報告がなされている.8 ${ }^{8111}$ ま た，溶接残留応力は極表層のみに存在する機械加工時の

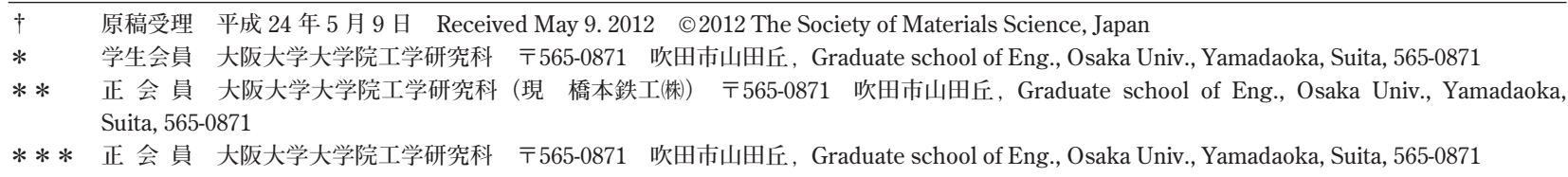


Table 1 Chemical composition of SUS316L used in this study (mass \%).

\begin{tabular}{ccccccccc}
\hline $\mathrm{C}$ & $\mathrm{Si}$ & $\mathrm{Mn}$ & $\mathrm{P}$ & $\mathrm{S}$ & $\mathrm{Ni}$ & $\mathrm{Cr}$ & $\mathrm{Mo}$ & $\mathrm{Fe}$ \\
\hline 0.019 & 0.66 & 1.19 & 0.033 & 0.001 & 12.11 & 17.41 & 2.05 & Bal. \\
\hline
\end{tabular}

残留応力と異なり板厚全体に存在することから, 主に SCC の進展に大きく寄与することが明らかになっており， 溶接時の残留応力分布を用いた SCC 進展の評価 ${ }^{12) ~ ~ 14) ~}$ が実施されている。ここで，配管の製作過程に注目する と, 内径合せの機械加工の後に突合せ溶接が施される. したがって，機械加工により生じた残留応力は，後の加 工としての溶接により変化することが考えられる．施工 後の実機運転を想定した応力変化等に関しては有用な知 見が得られている ${ }^{15)}$, 16)が，機械加工後の溶接といった 配管の施工過程に伴う残留応力変化挙動に関しては十分 な研究がなされていないのが現状である.

ここで，配管に打ける SCC の発生打よび進展に及ぼす 残留応力の影響を検討するためには, 実際の配管に存在 する残留応力分布を詳細に把握することが重要である. 本研究では, 機械加工および溶接といった複数の加工が 配管に施される場合の残留応力分布変化挙動の把握を試 みた。

\section{2 実 験 方 法}

\section{$2 \cdot 1$ 供試材および施工順序}

本研究では実機の配管施工を対象としているが，配管 では後述する残留応力測定が困難となるため，板材に対 して施工を行った，材料はオーステナイト系ステンレス 鋼 SUS316L を用い，溶体化処理後に以下に示す施工を 行った。本研究に打いて用いた試験片の化学組成を Table 1 に示す.配管の加工を想定して縦旋盤を用いた 機械加工を採用し，溶接はTIG アークを用いたビードオ ンプレート溶接を施した。試験片の寸法打よび施工の模 式図を Fig. 1 に示す，機械加工条件として，切削速度 $100 \mathrm{~m} / \mathrm{min}$, 送り速度 $0.1 \mathrm{~mm} / \mathrm{rev}$ ，切込み $0.1 \mathrm{~mm}$ とし た。溶接条件としては, 電流 $120 \mathrm{~A}$, 溶接速度 $2 \mathrm{~mm} / \mathrm{s}$, アーク長 $3 \mathrm{~mm}$ とした。また，溶接時のシールドガスと して流量 $15 \mathrm{l} / \mathrm{min}$ とした $\mathrm{Ar}$ ガスを用いた。本研究では 比較のため, 機械加工のみ, 溶接のみ, 機械加工後に溶 接，の 3 種の施工を試験体に対して施した。 以後, これ らを試験体 $\mathrm{M}, \mathrm{W}, \mathrm{M}+\mathrm{W}$ とする。

\section{$2 \cdot 2$ 残留応力測定}

試験体に各施工を施した後, 表面残留応力測定を行つ た。測定は $2 \mathrm{D}$ 法 ${ }^{17)}$ を用いたX X 線回折により行い, 装置 はBruker AXS 社製の D8 discover with GADDS を用いた。 装置の模式図打よび座標系を Fig. 2 に, 測定条件を Table 2 に示す。一般的にX 線回折による配向された溶 接金属や粗大粒などの残留応力測定においては，回折に 寄与する結晶粒の数が少なく, 測定が困難であることが 知られている。このような場合において，測定に対する 結晶粒を増加することが可能な摇動は有効な手法 ${ }^{18)}$ とな ることから, 溶接時の残留応力分布は溶接線方向に中央

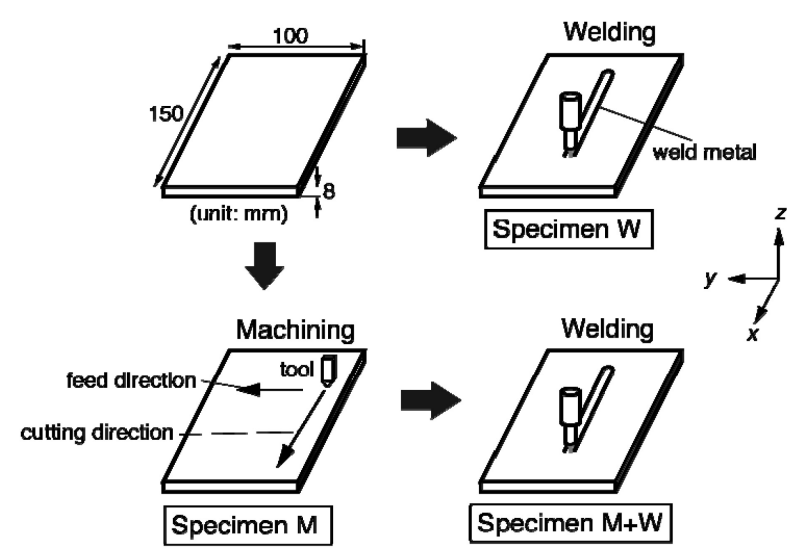

Fig. 1 Schematic illustration of manufacturing processes of each specimen.

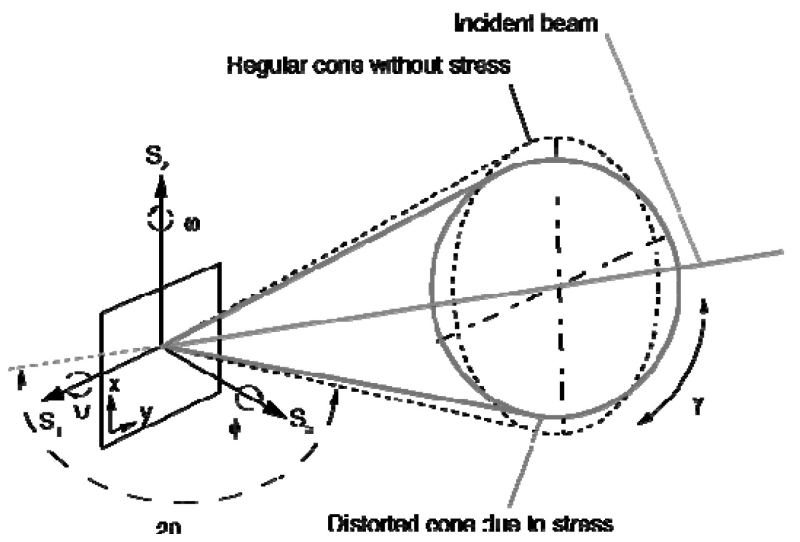

Fig. 2 Schematic illustration of X-ray equipment and coordinate system.

Table 2 XRD conditions for residual stress measurement.

\begin{tabular}{|c|c|}
\hline Wave length $(\mathrm{nm})$ & $0.2291(\mathrm{CrK} \alpha)$ \\
\hline Power $(\mathrm{kV}, \mathrm{mA})$ & 36,88 \\
\hline Beam size $(\mathrm{mm})$ & $\phi 1$ \\
\hline Diffraction peak $(\mathrm{deg})$ & $128(220)$ \\
\hline Measuring time $(\mathrm{s})$ & WM: $80, \mathrm{BM}: 30 \times 21 \mathrm{frame}$ \\
\hline Rocking & $\omega$ axis: $\pm 4^{\circ}, \mathrm{Y}$ axis: $\pm 2 \mathrm{~mm}$ \\
\hline
\end{tabular}

WM: weld metal, BM: base metal

に定常部を持つことを考慮し， $\omega, x$ 軸の多軸摇動を行う ことにより，残留応力測定の精度向上を試みた。また， 本研究では平面応力状態を仮定しており, 解析に必要な

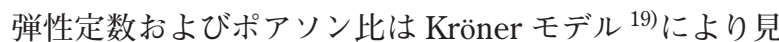
積もった $E_{220}=209.78 \mathrm{GPa}, v_{220}=0.278$ とした．測定は， 溶接中心から溶接直交方向に $20 \mathrm{~mm}$ までを $1 \mathrm{~mm}$ 間隔, その後は $5 \mathrm{~mm}$ 間隔で行った。 


\section{$2 \cdot 3$ ビッカース硬さ測定}

残留応力の変化挙動を評価するため, 各試験体に対し てビッカース硬さ試験を行った。試験装置は(株)島津製作 所製微小硬度計 HMV-1 を用いた。押し込み荷重 $490 \mathrm{mN}$, 保持時間 $15 \mathrm{~s}$ の条件で, 試験片断面において表面から $20 \mu \mathrm{m}$ の位置に打ける硬さ測定を行った。

\section{$2 \cdot 4$ 組織観察}

残留応力分布およびビッカース硬さ分布に及ぼす組 織変化の影響を検証するため, 電子後方散乱回折 (Electron Back Scattering Diffraction : EBSD) 法による 結晶方位解析を行った。加速電圧は $25 \mathrm{kV}$, 結晶方位の 測定ステップは $0.25 \mu \mathrm{m}$ とした。

\section{3 実 験 結 果}

\section{$3 \cdot 1$ 残留応力測定結果}

各試験体に対して残留応力測定を行った結果を Fig. 3 に示す．ここで，Fig. 1 に示したように， $x$ 方向は切削 および溶接方向, $y$ 方向は送りおよび溶接線直交方向で ある. 試験体 W の残留応力は, 溶接時の典型的な残留 応力分布を示して扣り, $x$ 方向に打いて, 溶接金属部打

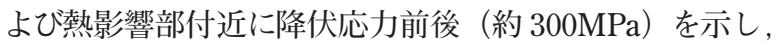
その引張応力と平衡を保つために他の領域において圧縮 残留応力を示す結果となった。 試験体 $M$ の残留応力分 布は全体においてほぼ一様な分布を示した。また，送り 方向の残留応力と比較して切削方向の方が高い引張応力

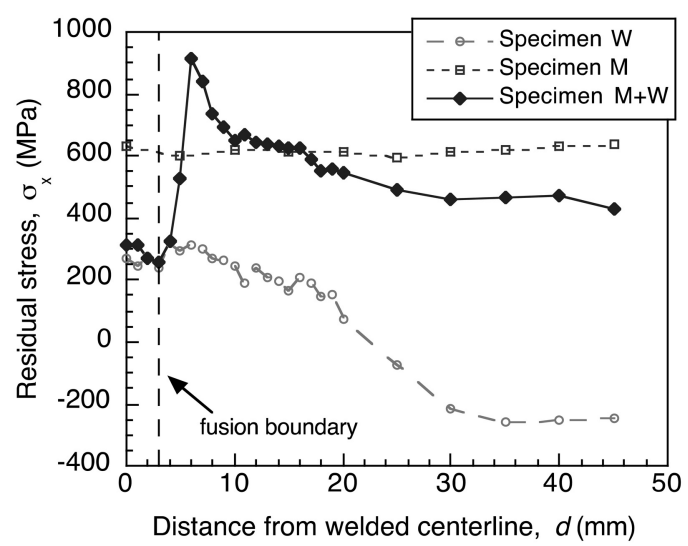

(a) Residual stress in $x$ direction

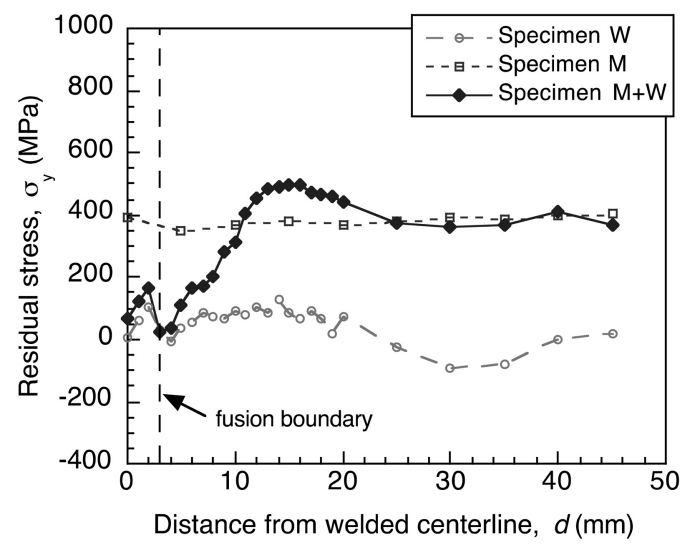

(b) Residual stress in $y$ direction

Fig. 3 Residual stress distribution measured by XRD for each processed specimen.
值を示しており，この值は材料の降伏応力を上回る結果 となった。このことから，機械加工により相当な加工硬 化が生じていることがうかがえる。試験体 $\mathrm{M}+\mathrm{W} に$ にお る $x$ 方向の残留応力分布は, 溶接金属（溶接中心から約 $3 \mathrm{~mm}$ ）内に扎て降伏応力と同程度の值を示すが, 溶接 金属より外側で急激に上昇し, 溶接中心から $6 \mathrm{~mm}$ の位 置において極大残留応力を示した。その後は試験体 $\mathrm{W}$ と 同様の傾向を示し，溶接中心からの距離とともに減少し た。また，この值は溶接時の残留応力のみならず，機械 加工時の残留応力よりも高い值を示した. $y$ 方向に扔い ても極大残留応力と見られる領域は発生しているが， $x$ 方向と比較して溶接中心からより離れた場所に存在して おり，また低い值を示している。一般的に溶接残留応力 は局所的な加熱・冷却に伴う熱膨張打よび収縮と，それ らに対する拘束により発生することが知られている。こ こでの拘束とは，加熱時に圧縮塑性ひずみが発生する溶 接金属部扎よび HAZ 部と，塑性ひずみが発生していな い母材部との収縮差により生じる。本研究に扎いては長 さ $150 \mathrm{~mm}$ の板に対して溶接長は $130 \mathrm{~mm}$ としているた め, $y$ 方向の拘束はほぼ生じない。しかしながら, $x$ 方向 では，溶接金属周辺で生じる大きな熱膨張に対して，端 部（溶接中心を $y=0$ として,$y= \pm 50 ）$ の熱膨張が小さ いため, 塑性ひずみに伴う拘束が発生し, 高い残留応力 が発生しやすい。したがって，施工過程に伴う残留応力 分布の変化挙動は $x$ 方向において顕著に現れていること が考えられる，以上の理由から，以後， $x$ 方向の極大残 留応力について検討を進めることとする.

\section{$3 \cdot 2$ ビッカース硬さ測定結果}

残留応力分布の変化挙動を検討するため, 各試験体に 対して溶接中心から $15 \mathrm{~mm}$ の位置までのビッカース硬さ 測定を行った。その結果を Fig. 4 に示す。ここで比較の ため, 熱処理後の試験体に対して 15 点の硬さ試験を行 い, その平均值 $(168.2 \mathrm{HV})$ を母材平均值として用いた。 試験体 $\mathrm{W}$ の硬さは全体にわたって母材平均と同様の值 を示した．また，試験体 Mに扎いても，ばらつきは大き いものの, 全体的に約 $325 \mathrm{HV}$ 前後の高い值を示した。 こ れは機械加工時の加工硬化によるものと考えられ，SCC

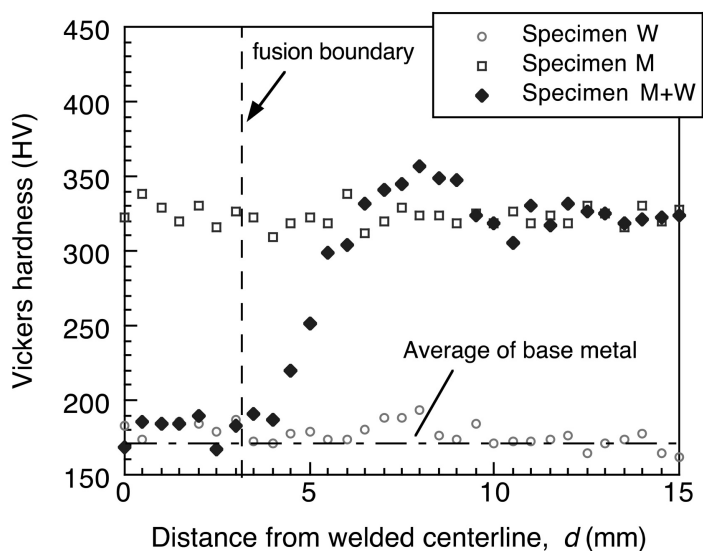

Fig. 4 Vickers hardness distribution of each processed specimen. 
発生時の硬さ ${ }^{6)}$, 7) と同様の值を示す結果となった。試験 体 $\mathrm{M}+\mathrm{W}$ は溶接金属近傍においては母材平均と同様の硬 さを示したが，溶接中心からの距離とともに硬さは上昇 し，6mm 前後の位置において機械加工ままの硬さと同 等の值を示した。その後，さらに上昇し， $8 \mathrm{~mm}$ において 極大硬さを示した後, 約 $10 \mathrm{~mm}$ 以降は機械加工ままの硬 さに収束する結果となった。この硬さの変化挙動は残留 応力分布の変化挙動と同様の傾向を示している。一般に 硬さは材料の塑性ひずみと相関があることが知られてお り，各測定点に打ける硬さはその位置において発生し得 る残留応力の大きさを示している，この極大硬さは機械 加工により導入された加工硬化に加え，溶接時において 加工層に熱サイクルが付与されることによる硬化が生じ た結果と考えられる。

\section{$3 \cdot 3$ 組織観察結果}

硬さ分布の変化挙動を検討するため, 試験体 $\mathrm{M}+\mathrm{W}$ に 対して EBSD 法による結晶方位解析を行った。測定領域 は $y-z$ 断面の溶接中心から $3.5,5.5,7.5 \mathrm{~mm}$ の 3 領域に対 して行い，それぞれ領域 A, B , C とした。これらの領域は 溶融境界近傍（領域 A), 極大硬化領域近傍（領域 C), およびそれらの中間点（領域 B）に対応している。これ らの領域に対して測定を行った結果のまとめを Table 3
に示す。それぞれ，逆極点図 (Inverse Pole Figure : IPF)， KAM (Kernel Average Misorientation) マップを示してい る. KAM マップに関しては転位密度や塑性ひずみとの関 連が示唆されており 20 , 21) 本研究においては機械加工によ り導入される塑性ひずみの定性的な評価に用いた。

これらの結果を比較すると他の領域に対して領域 A で は結晶方位回転やすべり線が一切確認できず，機械加工 による生じた塑性ひずみが見られない。さらに，結晶粒 径も他の領域と比較して小さく, KAM 值も低い值を示 していることから，領域 A では溶接熱サイクルに伴う再 結晶が生じたと考えられる。領域 B では機械加工時の塑 性ひずみは残存しているものの，領域 C と比較して明ら かにその量が減少していることが分かる。したがって， この領域においては溶接熱サイクルに伴う加工層での回 復が生じたと推測される。領域 Cにおいては結晶粒の回 転やすべり線だけでなく，強加工に起因するランダムな 菊池パターンを示す領域も表面近傍に多く存在している. 硬さ分布の観点からもこの領域 Cでは回復および再結晶 といった組織変化は見られないため, 機械加工時の塑性 ひずみがそのまま残存していると推測される。したがっ て，極大硬さは領域 C のような加工層が残存している領 域において生じるものであると推察される.

Table 3 Comparison of IPF and KAM maps at 3.5, 5.5 and 7.5mm from welded centerline of specimen $\mathrm{M}+\mathrm{W}$.

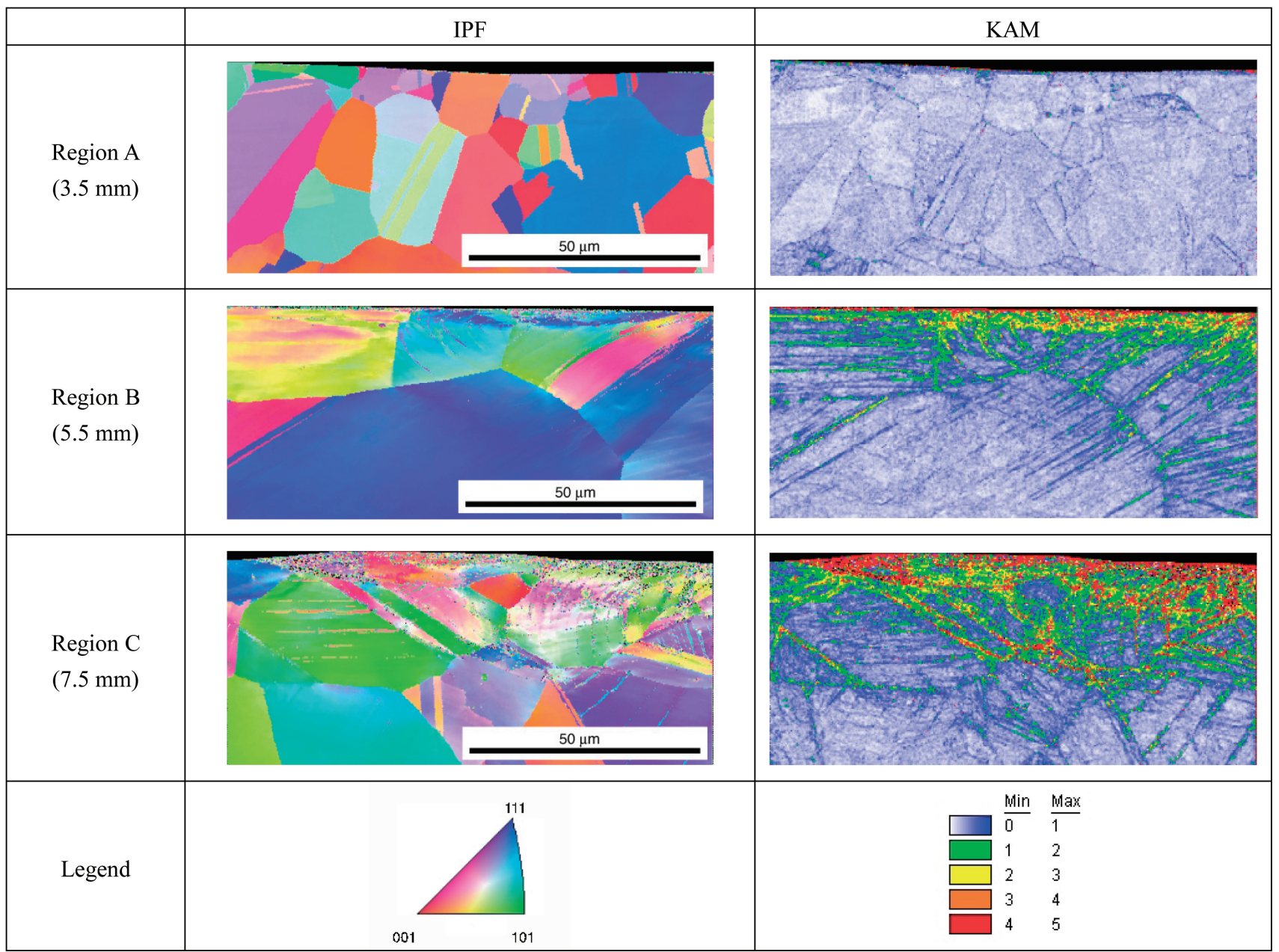




\section{4 考察}

上述のように，施工過程に伴う残留応力分布の変化挙 動は，溶接熱サイクルにより生じる回復および再結晶が 生じない領域，かつ，溶接残留応力が高い值を示す HAZ 部に扔いて極大残留応力を示すと考えられる，材料表面 において極大残留応力が生じる模式図を Fig. 5 に示す. 施工順序として機械加工後に溶接を施した場合の残留応 力分布は，既に機械加工により生じた残留応力分布が存 在する状態において溶接残留応力が発生する。つまり, 溶接残留応力は, 深さ方向に分布を持つ機械加工時の各 深さに打䂝留応力上に扎いて平衡を保つと考えられ る.これらの残留応力が重畳した結果として, 組織変化 する領域を除いた表面にて, Fig. 5 に示すような, 機械 加工時の残留応力に溶接時の残留応力を加算したような 分布が発生したと考えられる。溶接金属および溶融境界 近傍では再結晶, 回復が生じるため, 機械加工に伴って 導入された加工硬化が消失または減少し，機械加工まま の状態で受け持つことが可能であった応力を保てず，再 結晶が生じた領域においては母材の降伏応力に近い值を 示すと推測される.

加工層に溶接熱が作用した場合の硬化に関しては，炭 化物が析出した可能性が考えられる。加工方法や温度履 歴等の諸条件が異なるものの, オーステナイト系ステン レス鋼における加工層での炭化物析出は 316 鋼のみなら ず ${ }^{22)} 316 \mathrm{~L}$ 鋼においても報告されている.23)これらの研究 と本研究において一致することは加工層に対して熱サイ クルが作用していることである。加工層において, 加工 により導入された多数の転位が炭化物の核生成源となり うることで, 加工層に打いて炭化物が析出しやすい状態 が生じた結果, 極大硬さを示したと考えられる。しかし ながら，本研究で行ったような施工において炭化物析出 が発生したとは断言することができず，より詳細な材料 科学的検討は今後の課題である.

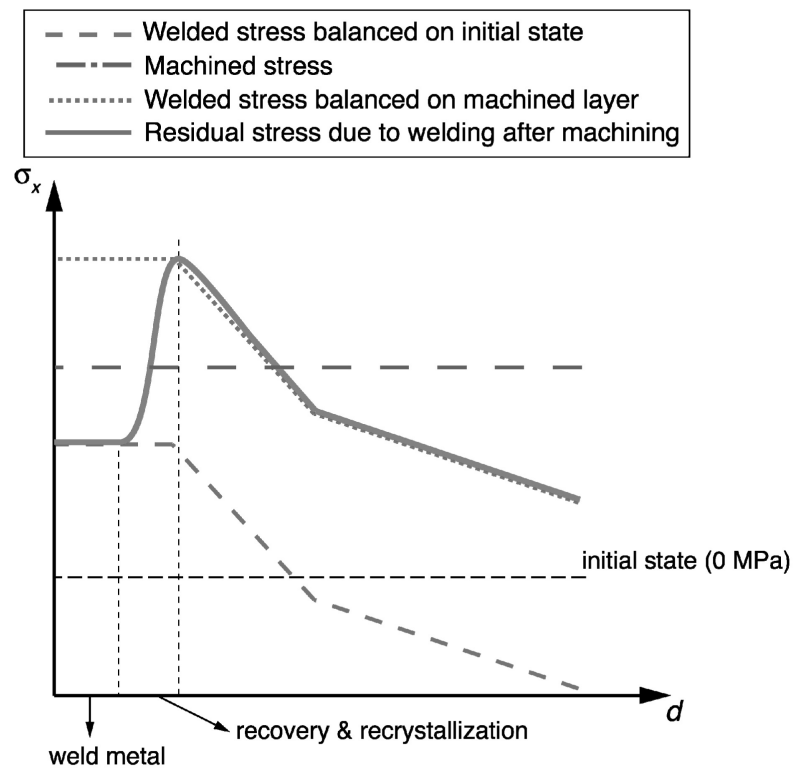

Fig. 5 Schematic illustration of variation of surface residual stress due to welding after machining.
施工過程に伴って発生する極大硬さは，270HV とされ る SCC が生じる硬さを上回っており，また，極大残留応 力に関しても SCC 発生限界応力として報告されている $600 \mathrm{MPa}$ を大きく上回っている，さらに，その発生位置 も SCC の顕在化領域と同様の HAZ 部であるといったこ とから, これら施工過程に伴う硬さと残留応力の変化挙 動はSCC 発生に関する重要な要因であると考えられる。

\section{5 結}

\section{言}

本研究ではオーステナイト系ステンレス鋼 SUS316L 製 配管の HAZ 部に顕在化している SCC に及ぼす残留応力 の影響を詳細に評価することを目的とし，実機の配管製 作時に行われる機械加工および溶接といった施工過程に 伴う残留応力分布の変化挙動を X 線回折により評価し た。さらに, 残留応力分布の変化挙動を検討するため, ビッカース硬さ試験および EBSD 法による結晶方位測定 を行った。得られた結果を以下に示す.

(1) 機械加工後の溶接に伴い, 残留応力分布は HAZ 部において極大残留応力を持つ分布形態が生じることを 示した. また，この極大残留応力值は機械加工または溶 接のみによって生じる残留応力よりも高い值を示した。

（2）硬さ試験の結果，施工過程に伴い，極大残留応 力が得られた領域近傍の HAZ 部において極大硬さを示 した.この極大硬さは機械加工により生じる加工硬化に 加え，加工層に溶接熱が付与された場合に生じる硬化が 生じた結果と考えられる。

（3） EBSD 法による結晶方位解析を行った結果，極大 硬化領域より溶接金属側では再結晶および回復が生じて いることを確認した。 また，極大硬化領域では溶接熱サ イクルに伴う組織変化を生じておらず，機械加工により 生じた塑性ひずみが残存していることを確認した。

(4) 施工過程に伴い生じる極大残留応力および極大硬 さはともに, SCC 発生のしきい值を大きく上回っており， 施工過程に伴う残留応力分布扎よび硬さ分布の変化挙動 はSCC 発生に関して重要な要因である考えられる。

本研究は, 研究拠点形成費補助金グローバル COE プ ログラム「構造・機能先進材料デザイン教育研究拠点」 (大阪大学) の研究費支援のもとに実施された。また，機 械加工試験に際し協力頂いた橋本鉄工(株殿に対し，ここ に感謝の意を表します。

\section{参 考 文 献}

1) Y. Okamura, A. Sakashita, T. Fukuda, H. Yamashita and T. Futami, "Latest SCC issues of core shroud and recirculation piping in Japanese BWRs", Transaction of the 17th International Conference on Structural Mechanics in Reactor Technology, WGO1-1 (2003).

2 ) S. Suzuki, K. Kumagai, C. Shitara, J. Mizutani, A. Sakashita H. Tokuma and H. Yamashita, "Damage evaluation of SCC in primary loop recirculation system pipe”, Maintenology, Vol.3, No.2, pp.65-70 (2004).

3 ) K. Takamori, S. Suzuki and K. Kumagai, "Stress corrosion cracking of L-grade stainless steel in high temperature water”, Maintenology, Vol.3, No.2, pp.52-58 (2004). 
4) J. C. Outeiro, D. Umbrello and R. M'Saoubi, "Experimental and numerical modeling of the residual stresses induced in orthogonal cutting of AISI 316L steel”, Machine Tools \& Manufacture, Vol.46, pp.1786-1794 (2006).

5 ) K. Takeda, A. Taniyama, T. Kudo, H. Uchida and J. Mizuki, "SCC behavior at hardened surface layer of 316 (LC) in water on high temperature”, Zairyo-to-Kankyo, Vol.58, pp.228-233 (2009).

6 ) M. Tsubota, Y. Kanazawa and H. Inoue, "Effect of cold work on the SCC susceptibility of austenitic stainless steels”, Proceedings of 7th International Symposium on Environmental Degradation of Materials in Nuclear Power Systems Water Reactors, Vol.1, pp.519-527 (1995).

7 ) N. Ishiyama, M. Mayuzumi, Y. Mizutani and J. Yani, "The effect of cold rolling and aging treatment on the stress corrosion cracking of SUS 316L stainless steels in high temperature water", Journal of Japan Institute of Metals, Vol.69, No.12, pp.1049-1052 (2005).

8 ) M. Tsubota, Y. Katayama and Y. Saito, "Stress corrosion crack growth behavior of cold worked austenitic stainless steel in high temperature water", Proceedings of the 12th International Conference on Environmental Degradation of Materials in Nuclear Power System -Water Reactors-, pp.109-114 (2005).

9) T. Masuoka, M. Mayuzumi, T. Arai and J. Tani, "Effect of work hardening on stress corrosion cracking propagation in SUS316L stainless steel”, Zairyo-to-Kankyo, Vol.56, pp.9398 (2007).

10) O. Raquet, E. Herms, F. Vallant and T. Couvant, "SCC of cold-worked austenitic stainless steels in PWR conditions”, Advances in Materials Science, Vol.7, No.1, pp.33-46 (2007).

11) J. Isselin, A. Kai, K. Sakaguchi and T. Shoji, "Assessment of the effect of cold work on crack initiation in a light water environment using the small-punch test”, Metallurgical and Materials Transactions A, Vol.39A, pp.1099-1108 (2008).

12) K. Miyazaki, M. Numata, K. Saito and M. Mochizuki, "Effects of distance from center of a weld to fixed end on residual stress and stress intensity factor of a piping weld”, Quarterly Journal of Japan Welding Society, Vol.24, No.1, pp.70-77 (2006).

13) K. Miyazaki and M. Mochizuki, "Effects of residual stress distribution and geometry of components on stress intensity factor and crack growth behavior of surface crack", Quarterly Journal of Japan Welding Society, Vol.24, No.1, pp.78-86 (2006).
14) H. Doi, S. Shibata, H. Inoue, H. Okada and G. Yagawa, "FEM automatic crack propagation analysis system for nuclear power plant using provided welding residual stress and its verification test”, Transactions of the Japan Society of Mechanical Engineers, Series A, Vol.76, No.772, pp.1527-1532 (2010).

15) T. Hashimoto, Y. Osawa, S. Itoh, M. Mochizuki and K. Nishimoto, "Long-term stability of residual stress improvement by water jet peening considering working processes", Transactions of the ASME, Journal of Pressure Vessel Technology, (2012) (to be published).

16) T. Hashimoto, T. Shobu and M. Mochizuki, "Consideration of microstructure evolution and residual stress measurement near severe worked surface using high energy X-ray", Journal of the Society of Materials Science, Japan (2012) (to be published).

17) B. B. He, "Introduction to two-dimensional X-ray diffraction”, Powder Diffraction, Vol.18, pp.71-85 (2003).

18) T. Hashimoto, Y. Osawa, S. Hirano, M. Mochizuki and K. Nishimoto, "Accuracy improvement of X-ray residual stress measurement in welds of $\mathrm{Ni}$ based alloy by two-dimensional detector with multiaxial rocking", Science and Technology of Welding \& Joining, Vol.16, No.3, pp.261-266 (2011).

19) E. Kröner, "Berechung der elastischen konstanten des vierkristalls aus den konstanten des einkristalls", Zeiteschrift Physik, Vol.151, pp.504-518 (1958).

20) M. Kamaya, A. J. Wilkinson and J. M. Titchmarsh, "Measurement of plastic strai of polycrystalline material by electron backscatter diffraction”, Nuclear Engineering and Design, Vol.235, pp.713-725 (2005).

21) A. J. Wilkinson, D. J. Dingley and G. Meaden, "Strain mapping using electron backscatter diffraction”, Electron Backscatter Diffraction in Material Science, Kluwer Academic/Plenum Publishers, pp.231-249 (2009).

22) A. H. Advani, L. E. Murr, D. G. Atteridge and R. Chelakara, "Mechanisms of deformation-induced grain boundary chromium depletion (sensitization) development in type 316 stainless steels”, Metal Transaction A, Vol.22, No.12, pp.2917-2934 (1991).

23) Y. Ohnishi, K. Fujio, E. Kakutani, A. Yamamoto, H. Tsubakino and M. Terasawa, "Changes in residual stress in low carbon stainless steel for nuclear reactor usage suffered from deformation and aging”, Journal of Japan Institute of Metals, Vol.72, No.5, pp.360-365 (2008). 